Fixed Point Theory, 21(2020), No. 1, 363-374

DOI: $10.24193 /$ fpt-ro.2020.1.25

http://www.math.ubbcluj.ro/ nodeacj/sfptcj.html

\title{
STABILITY OF MAXIMUM PRESERVING FUNCTIONAL EQUATION ON MULTI-BANACH LATTICE BY FIXED POINT METHOD
}

\author{
M.R. VELAYATI* AND N. SALEHI** \\ ${ }^{*}$ Department of Sciences, Najafabad Branch, Islamic Azad University, Najafabad, Iran \\ E-mail: mvelayat@iaun.ac.ir \\ ** Department of Sciences, Najafabad Branch, Islamic Azad University, Najafabad, Iran \\ E-mail: nsalehi@iaun.ac.ir
}

Abstract. We prove the stability of maximum preserving functional equation by substituting the addition with the maximum operation in Cauchy functional equation in multi-Banach lattice by fixed point method.

Key Words and Phrases: Multi-Banach lattice, maximum preserving functional equation, Cauchy functional equation, multi-normed spaces.

2010 Mathematics Subject Classification: 46B42, 34K20.

\section{REFERENCES}

[1] N.K. Agbeko, On optimal averages, Acta Math. Hung., 63(1994), no. 1, 133-147.

[2] N.K. Agbeko, On the structure of optimal measures and some of its applications, Publ. Math., 46(1995), no. 1-2, 79-87.

[3] N.K. Agbeko, A stability of maximum preserving functional equations on Banach lattices, Miskolc Math. Notes, 13(2012), no. 2, 187-196.

[4] N.K. Agbeko, S.S. Dragomir, The extension of some Orlicz space results to the theory of optimal measure, Math. Nachrichten, 286(2013), 760-771.

[5] T. Aoki, On the stability of the linear transformation in Banach spaces, J. Math. Soc. Japan, 2(1950), 64-66.

[6] D.G. Bourgin, Classes of transformations and bordering transformations, Bull. Amer. Math. Soc., 57(1951), 223-237.

[7] L. Cădariu, V. Radu, Fixed points and the stability of quadratic functional equations, An. Univ. Timişoara Ser. Mat-Inform., 41(2003), no. 1, 25-48.

[8] P.W. Cholewa, Remarks on the stability of functional equations, Aequationes Math., 27(1984), $76-86$.

[9] S. Czerwik, On the stability of the quadratic mapping in normed spaces, Abh. Math. Sem. Hamburg, 62(1992), 59-64.

[10] H.G. Dales, M.S. Moslehian, Stability of mapping on multi-normed spaces, Glasgow Math. J., 49(2007), no. 2, 321-332.

[11] H.G. Dales, M.E. Polyakov, Multi-normed spaces and multi-Banach algebras, Preprint.

[12] I. Fenyö, On an inequality of P.W. Cholewa, in: General Inequalities 5 (edited by W. Walter), Birkhäuser, Basel, 1987, 277-280. 
[13] P. Găvruta, A generalization of Hyers-Ulam-Rassias stability of approximately additive mappings, J. Math. Anal. Appl., 184(1994), no. 3, 431-436.

[14] D.H. Hyers, On the stability of the linear functional equation, Proc. Nat. Acad. Sci. USA, 27(1941), 222-224.

[15] D.H. Hyers, S.M. Ulam, Approximately convex functions, Proc. Amer. Math. Soc., 3(1952), 821-828.

[16] G. Isac, Th. M. Rassias, Stability of psi-additive mappings: applications to nonlinear analysis, Int. J. Math. Sci., 19(1996), 219-228.

[17] Y.-H. Lee, J.M. Rassias, Hark-Mahn Kim, Approximation of Jensen type quadratic-additive mappings via the fixed point theory, J. Comp. Anal. Appl., 21(2016), no. 4, 704-715.

[18] Th. M. Rassias, On the stability of the linear mapping in Banach spaces, Proc. Amer. Math. Soc., 72(1978), 297-300.

[19] Th. M. Rassias, Solution of a functional equation problem of Steven Butler, Octogon Math. Mag., 12(2004), 152-153.

[20] N. Salehi, S.M.S. Modarres, Stability of maximum preserving quadratic functional equation in Banach lattices, Miskolc Math. Notes, 17(2016), no. 1, 581-589.

[21] N. Salehi, S.M.S. Modarres, A fixed point method for the stability of a maximum preserving quadratic functional equation in Banach lattices, J. Fixed Point Theory Appl., 19(2017), 15151524, https://doi.org/10.1007/s11784-017-0423-3.

[22] F. Skof, Proprietá locali e approssimazione di operatori, Rend. Sem. Mat. Fis. Milano, 53(1983), 113-129.

[23] S.M. Ulam, A Collection of Mathematical Problems, Ser. Interscience Tracts in Pure and Applied Mathematics, No. 8, New York and London: Interscience Publishers, 1960.

[24] S.M. Ulam, Problem in Modern Mathemathics, Chapter VI, Science Editions, Wiley, New York, 1964.

Received: September 30, 2016; Accepted: February 23, 2017. 
